\title{
Stochastic Opponent Modeling Agents: A Case Study with Hamas
}

\author{
Aaron Mannes, Amy Sliva, V.S. Subrahmanian, Jonathan Wilkenfeld \\ University of Maryland \\ College Park, MD 20742, USA \\ amannes@umd.edu,asliva@cs.umd.edu,vs@cs.umd.edu,jwilkenf@gvpt.umd.edu
}

\begin{abstract}
Stochastic Opponent Modeling Agents (SOMA) have been proposed as a paradigm for reasoning about cultural groups, terror groups, and other socio-economic-political-military organizations worldwide. In this paper, we describe a case study that shows how SOMA was used to model the behavior of the terrorist organization, Hamas. Our team, consisting of a mix of computer scientists, policy experts, and political scientists, were able to understand new facts about Hamas of which even seasoned Hamas experts may not have been aware. This paper briefly overviews SOMA rules, explains how several thousand SOMA rules for Hamas were automatically derived, and then describes a few key findings about Hamas, enabled by this framework.
\end{abstract}

\section{Introduction}

Stochastic Opponent Modeling Agents introduced in $[2,3,4]$ were introduced as a paradigm for reasoning about any group $G$ in the world, irrespective of whether the group is a terror group, a social organization, a political party, a religious group, a militia, or an economic organization. SOMA-rules have been used to encode the behavior of players in the Afghan drug economy [5] as well as various tribes along the Pakistan-Afghanistan border [6].

In contrast to the groups initially examined using SOMA, Hamas is a major terrorist organization that has achieved international standing. Hamas, an Arabic acronym for Harakat al-Muqawma al-Islamiyya (Islamic Resistance Movement) is a terrorist organization that has carried out sophisticated attacks on Israeli targets. Hamas is also a sophisticated political organization that provides social services to the Palestinian people, has won elections, has an international presence among the Palestinian diaspora, and has links to states and like-minded organizations throughout the Muslim world. Long an important factor in the Israeli-Palestinian conflict, since winning the January 2007 Palestinian elections and taking de-facto control of Gaza, Hamas has become a major factor in Middle East politics.

Founded in 1987, Hamas is an off-shoot of the Gaza branch of the Muslim Brotherhood, an international Muslim organization devoted to establishing governments run according to strict interpretations of Muslim law.
According to its charter, Hamas opposes the existence of Israel and is committed to destroying it [7]. Initially, during the first Palestinian Intifada (Arabic for uprising) against Israeli authorities in the late 1980s and early 1990s, Hamas quickly took a leading role in organizing Palestinian strikes and protests. Later, Hamas (and several other Palestinian organizations) adopted suicide bombing as a tactic, carrying out a series of deadly bombings targeting Israel's bus system from 1994 to 1996 that killed over 80 people. One rationale for Hamas' turn to these larger-scale attacks was the February 25, 1994 massacre of 29 Muslim worshippers by an Israeli extremist. The bombings were also an effort to derail the Oslo Peace Process between the Palestinian Liberation Organization (PLO) and Israel. Hamas became the leading rival to the PLO in Palestinian politics. Hamas had established a network providing social services to the poorest Palestinians. The PLO, and particularly its primary component party Fatah, was dogged by charges of corruption and many Palestinians perceived Fatah as not responding to their needs. As Hamas' popularity grew, this rivalry occasionally turned violent [8].

In the 1990s Hamas established charitable organizations around the world to raise money. Officially the contributions support Hamas' humanitarian endeavors, but many analysts argue that the donations are fungible and support Hamas' violent activities. Hamas also built relationships with Iran, Syria (the organization's headquarters are in Damascus, Syria), Saudi Arabia, and Muslim Brotherhood factions around the world. Hamas also runs businesses in the West Bank and Gaza and is engaged in criminal activity, including counterfeiting and money laundering [9].

In September 2000, the al-Aqsa Intifada broke out. Hamas and the other Palestinian factions (including Fatah) joined together to fight Israel. Hamas carried out numerous suicide bombings and other attacks on Israeli civilians that, over the course of several years of violence, took hundreds of lives. Hamas has also engaged in increasingly sophisticated battles with Israeli forces including ambushes, IEDs, and mortar and rocket attacks [10]. Most Hamas suicide bombing emanated from the West Bank. Because it was more difficult to infiltrate Israel from Gaza, Hamas in Gaza has attempted to rockets that can strike Israeli population centers [11]. 
In January 2006 Hamas won an overwhelming victory in the Palestinian elections, winning 76 of 132 seats in the Palestinian legislature. However most of the international community re-fuses to negotiate with Hamas because of its refusal to recognize the existence of Israel and consequently, Fatah continued to hold political power. In June 2007, in a series of battles, Hamas took complete control of Gaza [12]. With effective control of a territory, growing military capabilities, and a strong reputation throughout the Arab world for its success in con-fronting Israel, Hamas is now a rising power in the region.

\section{SOMA Rule Derivation Methodology}

The Stochastic Opponent Modeling Agents (SOMA) framework, introduced in $[2,3,4]$, has been proposed as a general paradigm for reasoning about the possible behaviors of any group $G$, irrespective of whether the group is a terror group, a social organization, a political party, a religious group, a militia, or an economic organization. The SOMA system provides a probabilistic logic representation of group behaviors and several methods for reasoning about the types of actions a group may take in a given situation. Because SOMA makes no simplifying assumptions regarding the independence of possible actions, it is particularly effective for constructing models where the interaction and relationships between behaviors is uncertain, such as the behaviors of cultural groups or terror organizations. SOMA-rules have been used to encode the behavior of players in the Afghan drug economy [5] as well as various tribes along the PakistanAfghanistan border [6], as well as terror groups such as Hezbollah [18].

We derived SOMA rules from the Minorities at Risk Organizational Behavior (MAROB) dataset [13], which is an extension of the Minorities at Risk (MAR) dataset [14]. MAR tracks the repression, discrimination and political behaviors, such as rebellion and protest, for 284 ethnic groups worldwide. In an effort to better understand the nature of political violence, MAROB was created at the University of Maryland in 2005 to track behaviors and characteristics of ethnopolitical organizations, those claiming to represent MAR ethnic groups. As nine of the 14 most deadly terrorist organizations from 1998 to 2005 were ethnonationalist, MAROB reflects the importance of studying ethnopolitical organizations.

From a computational point of view, MAROB associates a relational database table with each group. The rows of the table reflect different years. The columns of the table denote different properties about the behavior of that group or about the environment within which the group functioned. For instance, a column such as KIDNAP specifies if the group used kidnapping as a strategy in a given year. Likewise, a column named FORSTFINSUP specifies if the organi-zation got financial support from a foreign state during a given year. The columns of any relational database table associated with a MAROB group fall into three categories: columns about actions that the group took (such as KIDNAP above), columns about the environment in which the group functioned (such as FORSTFINSUP above), and other administrative columns. Note that the environment can include information about actions that other groups took that contributed to the climate in which the group being modeled exists.

Our SOMA rule extraction method used MAROB data from 1987 to 2004 in order to extract rules about Hamas. A SOMA rule about a group $\mathrm{G}$ has the form

where:

$$
<\text { Action }>\text { : }[\mathrm{L}, \mathrm{U}] \text { if }<\text { Env-Condition }>
$$

- $<$ Action $>$ is an action that the group took (such as KIDNAP)

- <Env-Condition> is a logical conjunction of elementary conditions on the environ-mental attributes. An elementary condition associated with the environmental attribute $\mathrm{A}$ is an expression of the form $\mathrm{A}$ op value where op is in the set $\{=,<=,>=\}$.

- $[\mathrm{L}, \mathrm{U}]$ is a closed sub-interval of the $[0,1]$ interval.

The above rule says that in any year when the <EnvCondition $>$ is true, there is a probability between $\mathrm{L}$ and $\mathrm{U}$ that the group took the action stated in the rule. The rule below is an example of a rule that we extracted about Hamas.

\section{SUICIDE: [0.46] if Electoral Politics is not a Strategy.}

This rule says that in years when Hamas did not use electoral politics as a strategy, there was a $46 \%$ probability that they engaged in suicide attacks as a strategy.

The SOMA rule extraction method consists of three steps:

1. Select a value for $<$ Action $>$,

2. Fix one environmental attributes as part of $<$ EnvCondition>,

3. Add varying combinations of up to three of the remaining environmental attrib-utes to <EnvCondition $>$ to determine if significant correlations exist between $<$ Env-Condition $>$ and $<$ Action $>$.

Using the standard definition of confidence from the literature, the rule extraction method calculates the difference between the confidence value produced by $<$ Env-Condition> and its negation. If this difference exceeds a given threshold, then a SOMA rule is extracted. To ob-tain the probability range for the extracted rule, we use the confidence value plus/minus $\varepsilon$. This process is repeated for all combinations of environmental attributes and actions.

By analyzing the MAROB data for a period of 18 years, we identified thousands of rules for Hamas' behaviors. 


\section{Some Results About Hamas's Behavior}

Following is an analysis of some of the rules describing Hamas' behavior. This survey looks at rules relating to the probability of Hamas carrying out suicide attacks, bombings, kidnap-pings, targeting domestic civilian infrastructure, and participating in criminal activity. A basic paradigm that is useful for examining a terrorist group's activities is to examine two variables: the group's level of motivation and its operational capability [15]. The SOMA rules provide insight into the conditions that increase and decrease the probability of a group taking a particular action. The conditions will be examined according to whether they affect a group's capability for the action or its motivation. At times this may not be clear. The condition of receiving support from the diaspora community may reflect an increase in capability (diasporas can provide funding and other support) but it can also reflect a change in motivation (diasporas may influence the values of the group in question).

Some rules may not fit into either category, but may still shed significant insight into an organization's worldview, intentions, and operations.

The tables below provide a summary of the SOMA rules extracted for various actions under-taken by Hamas. In the left-hand column are the conditions and in the right-hand column is the probability, given these conditions, that Hamas will undertake the action. In the column containing the conditions a slash / represents a new rule. That is the conditions after a slash are not linked to the conditions before the slash in determining the probability. For example, in the fifth row in the table below there are two separate sets of conditions in which suicide attacks have a probability of .89 - the first set is before the slash and the second set comes after the slash. Parentheses () indicate different conditions that, when combined with another condition, have the same probability of an action being carried out. For example, in the table below in the fourth row, either of the conditions within the parentheses, when combined with the condition before the parentheses create a .91 likelihood of Hamas carrying out a suicide attack.

\section{Suicide Attacks}

Much of Hamas' notoriety has come from its deadly suicide bombings, which have taken hundreds of lives since Hamas adopted the tactic. Examining the SOMA rules in Figure 1 gives some insight into how suicide attacks reflect the organization's strategies.

One interesting correlation is between Hamas' provision of social services and the increased likelihood of launching suicide attacks. Hamas is frequently noted for providing much needed social services such as medical care and youth activities for the inhabitants of the West Bank and Gaza. These welfare networks have been essential to Hamas' growth in popularity. Providing social services also increases Hamas' capabilities for carrying out suicide bombings. The infrastructure for providing social services helps recruit members, provide for the families of suicide bombers, and in addition the facilities have reportedly been used as safe houses for operations [16].

\begin{tabular}{|l|l|}
\hline Conditions & Probability \\
\hline Involved in electoral politics & 1.0 \\
\hline Providing social services major strategy & .91 \\
\hline $\begin{array}{l}\text { Providing social services major strategy } \\
\text { \& (Periodic lethal violence from state }\end{array}$ & .9 \\
OR Clandestine) & \\
\hline $\begin{array}{l}\text { Providing social services is a major } \\
\text { strategy \& Representing interests to } \\
\text { officials is not a strategy / Support from } \\
\text { international NGO \& No support from } \\
\text { international governmental organization }\end{array}$ & \\
\hline $\begin{array}{l}\text { Provision of social services \& } \\
\text { (Periodic lethal violence from state }\end{array}$ & .83 \\
OR Clandestine) & \\
\hline $\begin{array}{l}\text { Provision of social services \& } \\
\text { Representing interests to officials is not } \\
\text { a strategy }\end{array}$ & .82 \\
\hline $\begin{array}{l}\text { State use of lethal violence against } \\
\text { organization \& (Internal and external } \\
\text { bases OR No support from international } \\
\text { government organization) / Internal and } \\
\text { external bases \& Clandestine }\end{array}$ & \\
\hline Electoral politics is not a strategy & .77 \\
\hline $\begin{array}{l}\text { No diaspora support / Electoral politics } \\
\text { is not a strategy \& Clandestine) }\end{array}$ & .42 \\
\hline
\end{tabular}

Figure 1 Summary of extracted SOMA rules for suicide bombings by Hamas

Another example of a rule reflecting Hamas' increased capabilities is the increased likelihood of suicide bombings in years when Hamas possesses internal and external bases. In 1991, Israeli authorities banished hundreds of Hamas leaders to Lebanon. While in Lebanon, Hamas came into contact with Hezbollah - one of the first terrorist organizations to adopt suicide bombings. The two organizations established a strategic alliance and Hezbollah provided training, while its patrons Iran and Syria began providing equipment and funding. With this increase in support, Hamas could undertake more complicated operations - such as suicide at-tacks [17].

Some conditions would obviously increase Hamas' motivation to launch suicide attacks, such as being attacked by the Israelis. Other conditions are not as clear. The strong correlation between receiving diaspora support and a high likelihood of suicide attacks may indicate that diaspora support increases Hamas capabilities. It is also possible that Hamas is attracting diaspora support because of its high-profile suicide attacks.

The high likelihood of suicide bombings in years when Hamas is receiving support from international NGOs but not from international governmental organizations may be linked to Hamas' social services networks. The international NGOs work with Hamas because it is the de- 
facto power on the Palestinian street and the only way to deliver social services.

Hamas suicide attacks are almost certain in years that Hamas participates in the Palestinian electoral process, and substantially less likely in years that they are not participating. However, it is probably not accurate to conclude that participating in the electoral process leads to increased suicide bombings. The likelihood of suicide bombings appears to have risen as Hamas has expanded in capabilities, as represented by the establishment of external bases where Hamas could receive training from its sponsors. But the Hamas' high likelihood of carrying out suicide attacks in years that it participates in the Palestinian electoral process does raise questions about the proposition that participation in electoral processes will lead to the organization rejecting violence.

\section{Bombings}

\begin{tabular}{|c|c|}
\hline Conditions & Probability \\
\hline $\begin{array}{l}\text { Diaspora support / Provision of social } \\
\text { services \& Inter-organizational conflict } \\
\text { / Soliciting external support is a major } \\
\text { strategy \& Electoral politics is not a } \\
\text { strategy }\end{array}$ & 1.0 \\
\hline $\begin{array}{l}\text { Provision of social services \& Electoral } \\
\text { politics is not a strategy }\end{array}$ & .88 \\
\hline $\begin{array}{l}\text { Provision of social services \& } \\
\text { Representing interests to officials is not } \\
\text { a strategy }\end{array}$ & .82 \\
\hline $\begin{array}{l}\text { Providing social services major strategy } \\
\text { \& State violence against org }\end{array}$ & .8 \\
\hline $\begin{array}{l}\text { Provision of } \begin{array}{c}\text { social services \& } \\
\text { support } \\
\text { from }\end{array} \text { international } \\
\text { governmental organization or } \\
\text { Clandestine) / Representing interests to } \\
\text { officials is not a strategy \& (Internal } \\
\text { and external bases OR Solicits external } \\
\text { support }\end{array}$ & .75 \\
\hline
\end{tabular}

Figure 2 Summary of extracted SOMA rules for bombings by Hamas

Bombing refers to attacks with explosive devices that are not suicide attacks (for example planted car bombs or IEDs). According to the rules in Figure 2 the likelihood of Hamas carrying out bombings is greatest in the years when Hamas is providing social services. As with suicide attacks, this may reflect how the social service networks augment Hamas' ability to undertake attacks by helping to recruit operatives and providing safe houses for planning operations.

There is a very high likelihood of Hamas conducting bombing attacks in years in which it is engaged in an inter-organizational conflict (most likely with Fatah) while also providing social services. The social service networks may play a role in expanding Hamas' capabilities to carry out such an attack, while the inter-organizational conflict may lead Hamas to carry out bombings in order to increase its standing among the Palestinian population.

\section{Kidnappings}

Kidnappings are also part of Hamas' arsenal of tactics. Hamas is currently holding an Israeli soldier captured in Gaza.

\begin{tabular}{|l|l|}
\hline Conditions & Probability \\
\hline $\begin{array}{l}\text { Provision of social services \& Inter- } \\
\text { organizational conflict }\end{array}$ & .83 \\
\hline $\begin{array}{l}\text { Solicits external support \& Inter- } \\
\text { organizational conflict }\end{array}$ & .75 \\
\hline $\begin{array}{l}\text { Inter-organizational conflict \& (Internal } \\
\text { and external bases OR No support from } \\
\text { international government organizations) }\end{array}$ & .71 \\
\hline Inter-organizational conflict & .67 \\
\hline Is clandestine & .35 \\
\hline
\end{tabular}

Figure 3 Summary of SOMA rules for kidnappings by Hamas

As shown in Figure 3 Hamas kidnapping activities appear to be strongly correlated with inter-organizational conflict with its Palestinian rivals. First and foremost, hostage taking is a useful means for terrorist organizations to raise their profile and to extract concessions from an enemy. This may be particularly useful in the context of Hamas' ongoing struggle with Fatah to dominate Palestinian politics. By holding Israeli hostages Hamas can press Israel to negotiate with them to re-lease the hostages. In addition to whatever practical concessions Hamas may seek to obtain, when Israel deals with Hamas (even through a third party such as Egypt) without Fatah, it reduces Fatah's standing as the internationally recognized representative of the Palestinians. A similar dynamic may be at play in the increased probability of kidnapping when Hamas is in a conflict with another Palestinian group and it is soliciting external support. In addition to raising the organization's profile in general, kidnappings give other states the opportunity to negotiate the hostage situations.

For all but one of the years of its existence from 1987 to 2004, Hamas has been clandestine. So this rule effectively represents the overall likelihood of Hamas engaging in kidnapping. The one year the organization was open, it carried out a kidnapping.

\section{Domestic Civilian Infrastructure Targeted}

Hamas became infamous for its high-profile suicide bombings. But it has also carried out at-tacks on civilian infrastructure that were not intended to take lives. Many of these attacks were efforts to dissuade Palestinians from interacting with Israel, such as burning buses that took Palestinians into Israel to work or destroying the market stalls of Palestinian merchants who dealt with Israel.

For the most part, Hamas used this tactic between 1989 and 1994 (with a return to it in 2000 and 2001 with the outbreak of the al-Aqsa Intifada) and it has a high 
correlation with inter-organizational violence in the rules in Figure 4. While Hamas used social services to increase its standing among the Palestinian population, it was also prepared to use violence to intimidate Palestinians to support its agenda. This could explain the increased likelihood of using this tactic during inter-organizational conflict. It also follows that Hamas would refrain from this tactic when engaged in the electoral process, since in that context it could backfire and turn Palestinians against them.

\begin{tabular}{|ll|l|}
\hline Conditions & & Probability \\
\hline $\begin{array}{l}\text { Inter-organizational conflict \& No } \\
\text { diaspora support }\end{array}$ & 1.0 \\
\hline $\begin{array}{l}\text { Electoral politics is not a strategy } \\
\begin{array}{l}\text { Inter-organizational conflict } \\
\text { Clandestine }\end{array}\end{array} \quad$ \& & .83 \\
\hline $\begin{array}{l}\text { Inter-organizational conflict \& \& } \\
\text { Clandestine }\end{array}$ & .75 \\
\hline $\begin{array}{l}\text { Electoral politics is not a strategy \& } \\
\text { Inter-organizational conflict }\end{array}$ & .71 \\
\hline Inter-organizational conflict & .67 \\
\hline $\begin{array}{l}\text { No support from international } \\
\text { governmental organization }\end{array}$ & .31 \\
\hline
\end{tabular}

Figure 4 Summary of SOMA rules for the targeting of domestic civilian infrastructure by Hamas

\section{Participation in Criminal Activity}

\begin{tabular}{|l|l|}
\hline Conditions & Probability \\
\hline $\begin{array}{l}\text { Electoral politics is not a strategy \& } \\
\text { (Provision of social services OR }\end{array}$ & 1.0 \\
Internal and external bases) & \\
\hline Internal and external bases & .86 \\
\hline
\end{tabular}

Figure 5 Summary of SOMA rules for the participation in criminal activity by Hamas

In order to fund its operations, Hamas primary criminal activity has been money laundering. The key factor, shown in Figure 5, was the acquisition of external bases, which helped Hamas develop international reach. The external bases put Hamas in touch with Hezbollah and its patrons Syria and Iran and allowed Hamas to expand its own network of international fundraising organizations.

The need to raise money to pay for its social services network is probably a motivating factor for Hamas to engage in criminal activity.

\section{Conclusions}

A review of the SOMA generated rules on Hamas behavior provides some potentially useful insights. According to the MAROB data, Hamas' efforts to target Israeli civilians and Israeli attacks on Hamas are virtual constants. However, the tactics Hamas employs do change and the SOMA rules shed some light on possible factors influencing these decisions. Two primary factors appear to shape Hamas' decisions about what tactics to employ, its capabilities (such as the presence of external bases or a social services network) and its position within Palestinian politics (such as being engaged in a violent confrontation with Fatah or the whether or not they are participating in the formal Palestinian political process.)

The rule reveals that Hamas is certain to carry out suicide attacks when it is engaged in the electoral process, however it would not be accurate to conclude that participating in the electoral process encourages suicide attacks. While there are five years in which Hamas participates in the electoral process, there are six years in which Hamas carries out suicide attacks when not participating in the electoral process. Therefore it cannot be stated with certainty that participating in the electoral process increases the likelihood of Palestinian suicide attacks, it also cannot be concluded that the opposite is true either. This is not a hypothetical question as Hamas won a majority of seats in the Palestinian parliament in 2006. They are currently the de-facto power in Gaza, and only international support for Fatah has prevented Hamas from taking power in the entire Palestinian Authority. The SOMA rules seem to indicate that as Hamas' capabilities expand the likelihood of carrying out high-profile attacks against Israel also increases, none of the rules indicate factors that might decrease Hamas' de-sire to target Israel.

The increased probability of some of Hamas' most violent activities in years when they are providing social services has similar implications. It is plausible that providing social services increases Hamas' capabilities. Even if this connection does not prove to be the case, there is also no evidence that taking on social welfare tasks has moderated Hamas. As Hamas expands its power in Gaza the, SOMA rules give every indication that the likelihood of Hamas attacking Israel will increase.

Perhaps the most interesting rules are those indicating the effect of inter-organizational conflict on the likelihood of Hamas undertaking violent activities. While overall Hamas violence against Israel is consistent, some tactics appear to be favored when Hamas is also in a conflict with other Palestinian groups. Since it was founded Hamas has clashed, sometimes violently, with the other major Palestinian group, Fatah. Hamas also has at time competed and at other times cooperated with Palestinian Islamic Jihad. Certain kinds of attacks, particularly kid-napping, can force negotiations (either with Israel or through third parties.) These negotiations effectively raise Hamas' status regionally and among the Palestinians. Hamas' need to raise its status among other Palestinians reinforces the importance of its social welfare network. While formal Palestinian political processes do not appear to change Hamas' behavior, the organization is influenced by its standing within Palestinian society. Whether internal Palestinian political dynamics can also foster conditions that might reduce the likelihood of Hamas carrying out violent attacks is an intriguing possibility. It is a proposition in the process of being tested, because as these conclusions are being written, Hamas is negotiating with 
Israel over a truce that would improve the daily lot of the Palestinians in Gaza but would also solidify Hamas' control of that territory.

\section{Acknowledgements}

The authors gratefully acknowledge funding support for this work provided by the Air Force Office of Scientific Research through the Laboratory for Computational Cultural Dynamics (LCCD) grants AFOSR grants FA95500610405 and FA95500510298, the Department of Homeland Security (DHS) through the National Consortium for the Study of Terrorism and Responses to Terrorism (START) grants N00140510629 and grant N6133906C0149, the Army Research Office under grant DAAD190310202, and the National Science Foundation under grant 0540216. Any opinions, findings or recommendations in this document are those of the authors and do not necessarily reflect the views of sponsors.

\section{References}

1. Amy Pate and Mary Michael of the University of Maryland's Center for International Development and Conflict Management provided invaluable comments and suggestions over the course of preparing this paper.

2. Simari G, Sliva A, Nau D, Subrahmanian V (2006) A stochastic language for modelling opponent agents. In: proceedings International Conference on Autonomous Agents and Multiagent Systems, 244-246.

3. Khuller S, Martinez V. Nau D, Simari G, Sliva A, Subrahmanian V (2007) Action Probabilistic Logic Programs, accepted for publication in Annals of Mathematics and Artificial Intelligence.

4. Khuller S, Martinez V, Nau D, Simari G, Sliva A, Subrahmanian V (2007) Finding Most Probable Worlds of Logic Programs. In proceedings Intl. Conf. on Scalable Uncertainty Management, Springer Lecture Notes in Computer Science Vol. 3442, pages 45-59.

5. Sliva A, Martinez V, Simari G, Subrahmanian V (2007) SOMA Modles of the Behaviors of Stakeholders in the Afghan Drug Economy: A Preliminary Report. In: Proceedings of the First International Conference on Computational Cultural Dynamics, pp. 78-86.

6. Subrahmanian V. (2007) Cultural Modeling in RealTime, Science, Vol. 317, Nr. 5844, pages 1509-1510.

7. The Covenant of the Islamic Resistance Movement Hamas: translated by the Middle East Media Research Institute, http://memri.org/. Also see: Halpern, O. (2006) Hamas working on 'new charter.' The Jerusalem Post, February 16.
8. Mannes, A. (2004) Profiles in Terror: The Guide to Middle East Terrorist Organizations. Rowman \& Littlefield, pp. 113-143.

9. Levitt, M. (2002) The Political Economy of Middle East Terrorism, Middle East Review of International Affairs, Volume 6, No. 4, December 2002.

10. Levitt, M. (2002) Hamas: Toward a Lebanese-Style War of Attrition? The Washington Institute for Near East Policy, Policy Watch \#367, February 26.

11. Mitnick, J. (2008) Why Hamas is a Growing Challenge for Israel, Christian Science Monitor, April 20.

12. Yaghi, M. (2007) Hamas's Authoritarian Regime in Gaza, The Washington Institute for Near East Policy.

13. Asal V, Johnson C, Wilkenfeld J (2007) Ethnopolitical Violence and Terrorism in the Middle East. In Hewitt J, Wilkenfeld J, Gurr T (eds) Peace and Conflict 2008. Paradigm, Boulder CO.

14. Minorities at Risk Project. College Park, MD: Center for International Development and Conflict Management. $2005 \quad$ Retrieved from http://www.cidcm.umd.edu/mar/.

15. Ganor, B (2005) The Counter-Terrorism Puzzle: A Guide for Decision Makers. Transaction, p. 30.

16. Levitt, M. (2004) Hamas from Cradle to Grave. Middle East Quarterly, Volume 9, Number 1, Winter 2004.

17. Stern, J. (2003) Terror in the Name of God: Why Religious Militants Kill. Ecco, p. 47.

18. Mannes A, Michael M, Pate A, Sliva A, Subrahmanian V, Wilkenfeld J (2008) Stochastic Opponent Modeling Agents: A Case Study with Hezbollah. In Proceedings Intl. Conf. on Social and Behavioral Processing, Springer Verlag Lectures Notes in Computer Science. 